\title{
O SILÊNCIO SOBRE O NEGRO NA CONSTRUÇÃO DA IDENTIDADE DE CURITIBA: MEMÓRIA E ESQUECIMENTO, DE TATIANE VALÉRIO ROGÉRIO DE CAMARGO $^{1}$
}

\author{
Maria Cleci Venturini \\ Universidade Estadual do Centro-Oeste, UNICENTRO, PR, Brasil
}

O trabalho dá visibilidade ao discurso do ódio decorrente da invisibilidade e do silenciamento do negro na construção da identidade da cidade de Curitiba, capital do Paraná. Para sustentar a sua tese, a doutoranda valeu-se dos escritos de Auguste de Saint-Hilaire (1995), Romário Martins (1995) e Wilson Martins (1989), que valorizam o imigrante europeu e a superioridade da raça branca em detrimento do negro/escravo, sinalizando para o discurso do ódio e da intolerância racial, perenizada em/por discursos.

Com vistas a mostrar a contradição nos discursos dos historiadores que depreciam o negro em detrimento dos imigrantes brancos, a doutoranda traz anúncios do Jornal $O$ Dezenove de Dezembro, do século XIX, que atestam não só a existência, mas também a tentativa de venda de escravos em Curitiba como se eles fossem mercadorias. A busca por materialidades que comprovam a existência de escravos e a participação deles na construção da identidade de Curitiba deve-se ao fato de os historiadores, dentre eles Wilson Martim, sustentarem, em seus textos, que essa foi uma das primeiras capitais a abolir a escravatura. A negação dessas questôes históricas na referida cidade traz como consequência a "invisibilidade" dos negros e o apagamento da sua contribuição na construção identitária da capital.

O corpus da tese constitui-se, portanto, dos discursos dos três historiadores, já citados, dos anúncios e de lugares - os quais a autora sustenta como "lugares de memória”, a partir de Pierre Nora -, destacando a visibilidade e a produtividade dos negros na identidade de Curitiba, por meio de fotografias, monumentos e espaços públicos. As análises realizadas sinalizam para o destaque que lideranças negras têm/tiveram, ao resistir à condição de violência a que os negros eram submetidos, criando espaços públicos que funcionam/funcionaram como lugares de resistência, de luta, de reuniôes que agregam/agregaram os que, por não aceitarem as condiçóes

\footnotetext{
1 Tese oreintada pela Profa. Dr. Lígia Negri, defendida em 2016, na Universidade Federal do Paraná. Texto integral disponível em: <http://acervodigital.ufpr.br/bitstream/ handle/1884/26304/Dissertacao_finalizada _Tatiane.pdf?sequence=1>. Acesso em: 06 jan. 2018.
} 
de desigualdade em vigência no período, protagonizam/protagonizaram movimentos e embates, convocando os demais a assumirem lugares e espaços na cidade.

O resultado dessas lutas, empreendidas quando da urbanização de Curitiba e da construção da identidade paranaense, é visível no espaço público por meio de lugares históricos pelos quais ressoa a participação dos negros na construção identitária de Curitiba. Dentre esses lugares, sobressaem-se: a Praça Zumbi dos Palmares, a Sociedade Treze de Maio e as Ruínas da Igreja de São Francisco. Este último espaço, construído pelos negros, faz retornar o pelourinho como o lugar em que se realizavam práticas de violência física contra os negros/escravos. Mesmo diante dessas evidências documentadas no espaço público, Wilson Martins discorre e defende a generosidade do povo paranaense, negando que o escravagismo perdurou até o final do século XIX.

Para discutir o espaço urbano de Curitiba, Tatiane apresenta uma concepçáo urbanística da cidade, a qual se materializa em discurso fundador, sustentando discursos e memórias da urbanização e da construção identitária do curitibano, que é construída também pelos negros, não só por brancos. $\mathrm{O}$ corpus e as análises mostram as contradiçóes e os antagonismos presentes nos discursos dos historiadores - que, mesmo tornando invisíveis os negros e recusando-se a aceitar a prática escravocrata no Paraná, terminam por serem desmentidos pelos espaços públicos, que rememoram/comemoram os negros, o que permite à doutoranda concluir e defender a impossibilidade de sustentação de uma identidade marcadamente branca, sem a presença e sem a contribuição do negro na sua história, como também destacam os textos fundadores da identidade paranaense analisados no estudo.

O texto de tese de Tatiane Valéria Rogério de Camargo possui cinco capítulos, ao longo dos quais ela mobiliza e discute os discursos fundadores, já mencionados, a construção ideológica da identidade curitibana, o papel e atuação da imprensa descortinando os discursos tidos como fundadores, os conceitos teóricos da Análise de Discurso e a prática do entremeio, e os lugares chamados "de memória", que dão visibilidade à identidade paranaense e que mostram o negro trabalhando, resistindo, fazendo parte do plano urbanístico de Curitiba, capital do Paraná. 